\title{
Health Policy in the Supreme Court and a New Conservative Majority
}

Lawrence O. Gostin

Georgetown University - Law Center - O'Neill Institute for National and Global Health Law, gostin@law.georgetown.edu

Wendy E. Parmet

Northeastern University

Sara Rosenbaum

Milken Institute School of Public Health, George Washington University

This paper can be downloaded free of charge from:

https://scholarship.law.georgetown.edu/facpub/2323

https://ssrn.com/abstract=3729461

The Journal of the American Medical Association, Vol. 324, No. 21, Pp. 2157-2158, 2020. DOI No.: 10.1001/jama.2020.21987. Published online October 27, 2020.

This open-access article is brought to you by the Georgetown Law Library. Posted with permission of the author. Follow this and additional works at: https://scholarship.law.georgetown.edu/facpub

Part of the Health Law and Policy Commons, and the Supreme Court of the United States Commons 


\section{Health Policy in the Supreme Court and a New Conservative Majority}

\section{Lawrence 0. Gostin, \\ JD \\ O'Neill Institute for National and Global Health Law, \\ Georgetown University, Washington, DC}

Wendy E. Parmet, JD

Northeastern

University, Boston,

Massachusetts.

Sara Rosenbaum, JD

Milken Institute School

of Public Health,

George Washington

University,

Washington, DC

Corresponding Author: Lawrence O. Gostin, JD,

O'Neill Institute for National and Global Health Law,

Georgetown University, 600 New Jersey Ave NW, McDonough 568 , Washington, DC 2000 (gostin@georgetown. edu).
Within $\mathbf{8}$ days of the death of Ruth Bader Ginsburg-a pioneer of women's rights and a liberal icon-President Trump nominated Judge Amy Coney Barrett to fill her seat. Her elevation to the Supreme Court will have profound consequences for health care and policy.

The Affordable Care Act

Justice Barrett opposed the Supreme Court's 2012 decision upholding the Affordable Care Act (ACA). In California $v$ Texas, ${ }^{1}$ to be argued on November 10, the Court will decide whether legislation zeroing-out the ACA's "shared responsibility" tax penalty renders the individual mandate unconstitutional and if so, whether the entire law must be invalidated. If the Court strikes down the law, insurance safeguards will be eliminated, including protection against preexisting condition exclusions. Invalidating the ACA could cause 20 million people to lose subsidized coverage, with the number of uninsured increasing to 50 million people. With the coronavirus disease 2019 (COVID-19) pandemic and rising unemployment, the consequences could not be greater.

\section{Medicaid Work Requirements}

The Department of Health and Human Services (HHS) allowed states to conduct experiments conditioning Medicaid eligibility on "community engagement," principally work. A federal appellate court vacated approval of Arkansas' demonstration project, ruling that HHS unlawfully approved such experiments, ignoring adverse effects on Medicaid coverage. Despite an evaluation of the Arkansas experiment documenting widespread loss of insurance, ${ }^{2}$ the administration has sought Supreme Court review, arguing HHS has virtually unreviewable powers to approve Medicaid experiments.

Access to Courts to Preserve Medicaid Benefits A Reconstruction-era statute known as $§ 1983$ gives individuals the right to challenge state actions that violate federal rights. The Supreme Court previously concluded that Medicaid creates a private right of action to enforce Medicaid's requirements through §1983. Conservative jurists have sought to end $\$ 1983$ protection, arguing the federal government is solely empowered to remedy state Medicaid violations. Without access to $\S 1983$, beneficiaries would be barred from seeking judicial relief if states deny Medicaid rights, such as prompt provision of benefits or choice of health care provider.

\section{Employer-Sponsored Health Plans}

The Employee Retirement Income Security Act (ERISA) regulates employer-sponsored insurance. States can regulate insurance, but ERISA exempts self-insured plans. On October 6, before Justice Barrett's confirma- tion, the Supreme Court heard arguments regarding whether states can regulate pharmacy benefit managers (PBMs), which administer coverage for employer plans. Should the Court find that ERISA preempts states from regulating PBMs in self-insured plans, it would impede states from regulating pharmaceutical pricing.

\section{Reproductive Rights}

In her confirmation hearings, Justice Barrett said Roe $v$ Wade was not a "super-precedent," opening the possibility of overturning this landmark case.

The Future of Roe $v$ Wade. A new conservative majority will have the votes to reconsider Roe if it reviews a Mississippi law banning most abortions after 15 weeks. ${ }^{3}$ Currently, 10 states have abortion restrictions designed to be "triggered" if Roe is overturned. ${ }^{4}$ Even if Roe is not overturned, the Court could grant states wide leeway in restricting abortions, diluting Planned Parenthoodv Casey's "undue burden" standard. Abortion-related cases pending in federal circuitcourts include bans on early-term abortions and on safe and common abortion methods. Laws also restrict abortion based on women's reasons and impose burdensome, medically unnecessary restrictions on centers providing abortion services. Laws narrowing abortion access will affect primarily low-income women, women of color, and those living in rural areas.

The Court will also decide the validity of the Food and Drug Administration's requirement that mifepristone be dispensed in person during the pandemic. In early October, the Court refused to allow the rule to take effect while a lower court considers a challenge by the American College of Obstetricians and Gynecologists.

Contraceptive Access and the Conscience Rule. In July, the Court upheld a rule allowing employers with religious or moral objections to exclude contraceptive coverage. ${ }^{5}$ The lower courts are now determining the validity of the rule, and the issue could return to the Supreme Court. The Court could also review the administration's "conscience rule," which allows clinicians to refuse to treat patients when doing so conflicts with their religious or moral beliefs.

Title X Family Planning "Gag" Rule. Title X provides grants for low-income patients for family planning and reproductive health services, including contraception, treatment for sexually transmitted infection, and screening for breast cancer and cervical cancer. Title $\mathrm{X}$ regulations, however, prohibit paying for abortions. In 2019, HHS resuscitated a 3-decades-old "gag rule" prohibiting Title $X$-funded clinics from counseling patients about their options, including abortion. The rule also requires Title $X$-funded clinics to maintain financial and physical "separation" from abortion services. Many Title X clinics have left the program, reducing by 
half the capacity to provide these services. ${ }^{6}$ With the circuit courts in conflict over the validity of the rule, the American Medical Association has sought Supreme Court review.

Undoubtedly, Justice Barrett's appointment to the Supreme Court will reshape reproductive rights. A new administration could expand access to abortion services. Otherwise, state law, often with severe restrictions, may be individuals' only source of protection.

Public Health Powers During the COVID-19 Pandemic Litigation over COVID-19 responses could reshape public health powers. States have exercised a range of emergency powers, including stay-at-home orders, mask mandates, and bans on public gatherings. Litigants have launched dozens of lawsuits. So far, most courts have rejected challenges to emergency orders, relying on the Court's landmark decision in Jacobson v Massachusetts (1905), which affirmed a smallpox vaccination mandate. Jacobson grants states wide discretion in exercising public health powers.

Religious Liberty. A split 5-4 Supreme Court refused to overturn state limits on religious worship twice this year. Chief Justice Roberts cited Jacobson saying the "Constitution principally entrusts the safety and the health of the people to the States." ${ }^{\text {"7 }}$ He noted that states had imposed similar limits on secular gatherings. Yet, with the addition of Justice Barrett-who has an expansive view of religious libertythe Court could be more receptive to free exercise challenges.

The fate of many public health laws could be decided in Fulton $v$ City of Philadelphia, scheduled for argument in early November. The Court will decide whether cities may refuse to approve foster care agencies that will not accept same-sex foster parents. The Court may reconsider a vital 1990 decision, upholding "generally applicable" state laws that do not specifically discriminate based on religion. If the Court expands religious freedom, states might have to exempt religious objectors from health and safety laws, potentially including vaccination mandates.

Economic Liberty. The nation remains divided about whether business closures pose an excessive burden on economic activity. For nearly a century, the Supreme Court has not afforded business interests special constitutional protection, but a more conservative Court may. Recently, a federal district judge invalidated Pennsylvania's emergency order limiting indoor gatherings to 25 persons and closure of "non-life-sustaining" businesses. Citing the Supreme Court's widely discredited 1905 decision in Lochner v New York, the Court found the order violated "economic due process."8

Nondelegation. The nondelegation doctrine holds that legislative bodies cannot delegate lawmaking functions to agencies like health departments. The Supreme Court has not struck down a law on nondelegation grounds since 1935, but opponents of the regulatory state, including Justice Alito, have sought to resurrect the doctrine. The Michigan Supreme Court relied on nondelegation to invalidate the governor's emergency COVID-19 orders. A conservative Court could revive the doctrine to invalidate federal laws, including the Public Health Services Act, under which the Centers for Disease Control and Prevention temporarily banned evictions during the pandemic.

\section{Immigration and the Census}

The US Census is critical to political districting and allocation of federal resources, including to support health. In November, the Court will hear Trump $v$ New York to determine whether the census must count unauthorized immigrants. The Supreme Court has also agreed to hear challenges to President Trump's funding of a border wall and requiring asylum seekers to remain in Mexico while their claims for asylum are decided. Justice Barrett has been deferential to the administration's immigration restrictions, including supporting the public charge rule, which impedes access to public benefits (food, public housing, and Medicaid) for lawfully present immigrants.

\section{Firearm Regulations}

Since in 2008 the Court ruled that the Second Amendment confers an individual right to own a firearm, lower courts have upheld most state regulations. Yet 4 justices have urged stronger Second Amendment protections. In a 2019 dissent, Justice Barrett said a federal ban on felons owning guns was unconstitutional because in 1791 only dangerous felons were prohibited. ${ }^{9}$ If other justices embrace "originalism," firearm control laws could be overturned, including age restrictions, bans on high-capacity magazines and assault weapons, and even popular red-flag laws allowing families or police to petition courts for temporarily removing firearms from potentially violent persons.

\section{Conclusion}

As the ultimate authority over the meaning of law, the Supreme Court has, over centuries, influenced US society and the direction of policy. Whether the issue is basic health insurance, reproductive freedoms, or the power to safeguard public health in a deadly pandemic, the justices will have an opportunity to determine the future of health policy and the nation's health. The death of Justice Ginsburg and the confirmation of Justice Barrett may well contribute to a very different future.

\section{ARTICLE INFORMATION}

Published Online: October 27, 2020.

doi:10.1001/jama.2020.21987

Conflict of Interest Disclosures: None reported.

\section{REFERENCES}

1. United States Supreme Court docket No. 19-840 (consolidated with Texas v California, docket No. 19-1019). Accessed October 7, 2020. https://www. supremecourt.gov/search.aspx?filename=/ docket/docketfiles/html/public/19-840.html

2. Sommers BD, Goldman AL, Blendon RJ, Orav EJ, Epstein AM. Medicaid work requirements-results from the first year in Arkansas. N Engl J Med. 2019; 381(11):1073-1082. doi:10.1056/NEJMsr1901772

3. Dobbs v Jackson Women's Health Org., 951 F3d 246 (5th Cir 2020), petition for cert. pending No. 19-1392 (March 16, 2020).

4. Guttmacher Institute. Abortion policy in the absence of Roe. October 15, 2020. Accessed October 16, 2020. https://www.guttmacher.org/ state-policy/explore/abortion-policy-absence-roe

5. Little Sisters of the Poor v Pennsylvania, $140 \mathrm{SCt}$ 2367 (2020).

6. Dawson R. Trump administration's domestic gag rule has slashed the Title $X$ network's capacity by half. Guttmacher Institute. February 5, 2020.
Updated February 26, 2020. Accessed October 8, 2020. https://www.guttmacher.org/article/ 2020/02/trump-administrations-domestic-gagrule-has-slashed-title-x-networks-capacity-half

7. S. Bay United Pentecostal Church v Newsom, 140 SCt 1613 (2020) (Roberts CJ, concurring).

8. County of Butler v Wolf, No. 2:20-cv-00677-WSS (WD Pa September 14, 2020).

9. Kanter v Barr, 919 F3d 437, 451 (7th Cir 2019) (Barrett J, dissenting). 